\title{
China's Implementation of Panda Diplomacy in Indonesia: A Review of Constructivist Perspectives
}

\section{Arif Darmawan \& Reza Desfarika Putri}

\section{Arif Darmawan}

$\begin{array}{lcl}\text { Affiliation } & : & \text { Universitas Jenderal } \\ & & \text { Soedirman } \\ \text { City } & : & \text { Purwokerto } \\ \text { Country } & : & \text { Indonesia } \\ \text { Email } & : & \\ \text { arif.darmawan } @ \text { unsoed.ac.id }\end{array}$

Reza Desfarika Putri

$\begin{array}{lcl}\text { Affiliation } & : & \text { Universitas Jenderal } \\ & \text { Soedirman } \\ \text { City } & : & \text { Purwokerto } \\ \text { Country } & : & \text { Indonesia } \\ \text { Email } & : & \\ \text { rezadesfarika18@@gmail.com }\end{array}$

History

$\begin{array}{lll}\text { Submission } & : & \text { 20 December } 2020 \\ \text { Review } & : & \text { 4 February } 2021 \\ \text { Completed } & & \\ \text { Accepted } & : & \text { 25 February } 2021 \\ \text { Available } & : & \text { 26 February } 2021 \\ \text { Online } & & \end{array}$

DOI :

10.51413/jisea.Vol2.Iss1.2021.1-29

\section{Copyright}

This is an open access article distributed under the term of the creative commons attribution 4.0 international licence

\begin{abstract}
Bilateral relations between China and Indonesia have increased in recent years. Indonesia considers as a strategic partner of China in Southeast Asia. The application of Panda Diplomacy is proof that China considers Indonesia as a friendly country that has a significant meaning. Through the application of Panda Diplomacy, China strives to show a face that is friendly and does not pose a threat to other countries. In this article, we will discuss how the implementation of Panda Diplomacy by China in strengthening bilateral relations between China and Indonesia which will analyse through a constructivist perspective. This perspective views that the performance of Panda Diplomacy is a diplomacy tool and a symbol of friendship to shape a better Chinese image and identity. Here Constructivists see that Panda Diplomacy is a form of symbolic interaction. In carrying out panda diplomacy, indeed, China Government has thought of any strategies that can help in smoothing their national interests. So, Constructivists see this as an ideational focus on intersubjective beliefs as ideas, conceptions, and assumptions. However, there are other interests that China wants to achieve through a close relationship with Indonesia
\end{abstract}

Key Words: Soft Power, Panda Diplomacy, Constructivism, Bilateral Relations

\section{Cite this article :}

Darmawan, A., \& Putri, R. D. (2021). China's Implementation of Panda Diplomacy in Indonesia: A Review of Constructivist Perspectives. Journal of International Studies on Energy Affairs, 2(1), 1-38. https://doi.org/10.51413/jisea.Vol2.Iss1.2021.1-29 


\section{INTRODUCTION}

China is one of the countries using soft power in diplomacy, one of which is by carrying out Panda Diplomacy. As the home country for pandas, China takes Panda Diplomacy to countries that consider being strategic partners. Panda is used as a diplomacy tool by China because panda is attached to Chinese culture. The Chinese believe that the panda is an animal with a symbol of friendship and peace, so the country that chosen to carry out the Panda Diplomacy is considered a friend of China. Lending panda carries out this diplomacy to bread (breeding loan), and the recipient country must pay a rental fee of the US $\$ 1$ million or Rp. 13 Billion in one year (Muzakki, 2017). The two countries will make a cooperation agreement with the agreed time frame. This Agreement will run when China and the recipient country feel this transaction will give a positive impact on panda conservation. China itself has international rules regarding panda that must be followed by receiving countries in the Convention on International Trade in Endangered Species of Wild Fauna and Flora (CITES) (Furthermore is called CITES) (CITES, 1996).

Panda is used as a diplomatic asset because China uses it as political symbolism. The criteria in Panda Diplomacy is not only regarding the recipient country being a country that has a good financial situation for the zoo, but also considerations in the political field. This new form of diplomacy also illustrates that China has found an international partner willing to pay and finance one of the leading diplomacies. This is done by taking advantage of the global appeal of its national treasure that is a panda. China does not need to do anything more except animal-friendly, and a national partner who will provide that infrastructure for China's diplomatic tools (Hartig, 2013, p. 67).

Panda diplomacy was increasingly and carried out by China when under President $\mathrm{Xi}$ Jinping, almost every year Xi Jinping sent pandas to various countries. Xi Jinping also believes that through this diplomacy, China can achieve its right image in international society, and it can promote a culture to promote national interests. Panda's Diplomacy also motivated by the earthquake that occurred in Sichuan 2008, which resulted in a drastic reduction in the panda population, which was 60 left. Since that, China has stated that Panda Diplomacy is only for breeding and biological research, Canada became the first country chosen by Xi Jinping and continued to Austria. In 2014 was continued in two countries, namely Belgia and Malaysia (Islami, 2015). Delivery of pandas continues, South Korea became the country chose in 2016, and 20173 countries received pandas, namely Netherlands, Germany, and the last one until now, namely Indonesia (Setyani, 2017). 
Indonesia is the $16^{\text {th }}$ country to receive Panda Diplomacy. Panda Diplomacy in Indonesia started in 2010, but China only offered Panda Diplomacy when the two countries were celebrating the 6oth "Year of China-Indonesia Friendship". President made a direct offer of China Hu Jintao to President of Indonesia Susilo Bambang Yudhoyono (SBY). Furthermore, Panda Diplomacy in Indonesia implemented in 2017 under the leadership of Joko Widodo. The arrival of pandas to Indonesia shows the efforts of the government of China to strengthen relations between the two countries. The implementation of Panda Diplomacy is following China's Foreign Policy and Economic Policy which want the ancient silk route to revive through the land silk route and the sea silk route. The One Belt One Road (OBOR) policy also makes China believe in Indonesia as a strategic place and plays a role in the maritime silk route connecting east and west (Berty, 2017).

Through Panda Diplomacy, China not only conveyed the meaning of the panda according to Chinese culture, but the panda has become an iconic animal of China Culture and as a symbol of friendship and peace. Hartig (2013: 57) states that Animal symbolism can also indicate the expression of the national character of a country, so the panda as a unique and attractive animal has given symbolism which makes it a natural representation and a neat depiction of a nationality and state identity. Panda has also seen as a symbol of cooperation that expresses goodwill, and through Panda Diplomacy, the recipient country must take care of pandas for a long time and at the same time demonstrate a commitment to relations with China. Following the Guanxi concept, gifts given by other countries have an essential role in determining relations between nations (Buckinghamn, David, \& Jepson, 2013, p. 265).

The soft power approach through Panda Diplomacy is also part of China's strategy to approach countries in the Southeast Asian region, especially Indonesia, which is in the Malacca Strait area. China does face what is known as the Malacca Strait Dilemma or Malacca Dilemma related to China's geopolitical interests in the region. The Strait of Malacca indeed has a strategic value for China because this country is the largest user state with $80 \%$ of its oil imports passing through this region, which is driven by the rapid industrialization process in China that requires an extensive supply of petroleum (Rahmadani, S. Kusmanto, H. \& Warjio, 2019). On the one hand, the Chinese government wants to reduce dependence on oil imports through the Strait of Malacca, because it is prone to sabotage, robbery, and intervention by large countries that influence the region, such as the United States and India which may have proxies in countries adjacent to the Strait of Malacca. For China, the security of the Malacca Strait is fundamental with efforts to import petroleum from the Middle East. On the other hand, China's dependence on this region is very high related to China's petroleum energy needs. Various strategies have been 
implemented by China, such as the Belt \& Road Initiative, the String of Pearls, and efforts to build the Kra Canal in Thailand, including the soft power approach, one of which has implemented through Panda Diplomacy, towards countries in the Malacca Strait region, in particular. is Indonesia.

This paper will analyze how the implementation of Panda Diplomacy by China in bilateral relations with Indonesia from 2017 to 2019 using a constructivist perspective.

\section{LITERATURE REVIEW}

Constructivism is a perspective that changes the approach in international relations. If liberals and realists who see material and agent-centric matters in international relations and the state are given interests or do not have inherent interests, Constructivism sees that the state is not a shared interest because there are norms within the state, which makes the form inseparable from the social structure (Rachmawati, 2018, p. 28). In Constructivism, Wendt said that the reality of international politics is the result of the social construct of the social system, and ideas and symbolic interactions are the way the state relates to one another. When carrying out international relations, countries not only cooperate but also try to change their self-conception towards development. The attempt by China to create an identity is to increase its status in the international hierarchy. The symbolic formation of actions and actors can change a policy, and this depends on how important the actor is considered in culture and also allows political actors to manipulate the cultural details needed in political identification (Guzzini \& Leander, 2006, p. 50).

According to Hadiwinata (2017), Constructivism has two main ideas in international relations: first, material strength is not a structure that unites humankind but is determined by shared ideas. Second, shared ideas ascertain the identity and interests of actors rather than natural factors. Actors will act to do something not based on their motives but, actions have shaped by interactions between individuals in their surrounding environment such as social, political, economic, cultural and other structures. This illustrates that the social world is not a given, the laws of the social world cannot be determined from scientific research and explained through scientific theory because the social world is intersubjective (Hermawan, 2017, pp. 20-21).

Nye (2008) explains that the power of a country is determined by the ideas presented. Material capability is indeed necessary, but this material will be more useful when the state can form an interaction pattern that looks at the situation. 
Strength, according to constructivism, is the ability of actors to interpret intersubjective that will shape the structure of international relations and actor identity. Simply put, power is an effort to produce meaning to reality. Constructivists also see that the interest is not a finished product but must go through the stage of interpretation in interactions. So that national interest is the product of a theoretical view of the international context (Rosyidin, 2015, pp. 2324). Constructivism sees that the interactions carried out by actors produce various dimensions that are construction such as discourse, opinion, identity, values, norms, culture and others. Dynamic ideas will determine how actors perceive themselves and their environment. Andrew Bradley Phillips said: “..., constructivists' focus on the role played by ideational factors..." in international relations actors will determine their identity, interests and take action (Hermawan, 2017, p. 21).

The State, like humans, is an actor in international relations which has attributes in it such as rationality, identity, interests and beliefs, as well as the State. This attribute will affect how the actor acts. Wendt (1992) emphasizes that "Actors use ideas to construct relationships and material reality. So ideas precede negotiations and interpret history to make relationships either conflictual or cooperative". The State will take policies by weighing excellent or flawed (the logic of appropriateness) rather than profit or loss (the sense of consequences), this shows that the State is not an actor who is concerned with personal interests (selfhelp), the State will respect existing norms and regulations so that by other countries. This shows that the international community recognizes national interests. Constructivists see that state loss is a loss of trust caused by previous inappropriate actions (Rosyidin, 2015, p. 27).

The concept of identity can identify from 2 ideas. First, identity in the 'social' category, this identity will be formed in society when there is interaction with other parties (significant other) and causes a social construct process. So it takes intersubjectivity to give the meaning of "who am I/you", and this identity can quickly change depending on the definition in the process of actor interaction. For example, identity as a democratic country, human rights defender and others. Second, "personal" identity, which is an identity that already exists within the actor and does not require other actors in the formation of that identity. This identity is recognized by the actor himself (self-awareness), and the actor sees himself as a unique person because there are differences with other actors. Examples are ethnic, cultural, religious and other identities (Rosyid in, 2015, pp. 46-47).

In international relations, Wendt (1999) categorizes four kinds of identity. First, personal identity (corporate identity), which is an attribute of the state that makes a country different from other countries, and the state has an individual identity 
that other countries do not have. Second, type identity, which is an identity that classifies a country into specific categories; this depends on the inherent characteristics of the country. Third, role identity, which is an identity that sees the state's position in international relations and concerning the state's responsibilities when faced with specific situations. This identity requires an intersubjective to know the place of the actor. Fourth, collective identity, namely identity formed when actors have the same interests, so that these actors will take action together. In constructivists, identity is an attribute attached to the actor that will determine the actor's movements. Identity is also fundamental in the meaning of actors in their environment. The actor's awareness and understanding of himself provide a sense in acting (Rosyidin, 2015, pp. 50-57).

National identity becomes a link between citizens, both individuals and fellow citizens. When the identity of a country has been built and becomes a general identification, it will influence individual behaviour and form a national society to maintain national identity. The dynamics of national identity also depend on the national public, and as a public group that can influence the general public, they will try to protect and enhance national identity. Three aspects can affect the dynamics of national identity, first, namely external forces such as the image of the international environment that can mobilize the dynamics of national identity. Second, internal forces such as the government of a country that has the authority to build an image to mobilize the dynamics of national identity. Third, namely, factors beyond government control. This identity can influence government foreign policy (Bloom, 1990, pp. 79-80).

The identity of actors, which is the result of the social construct of norms and creates the interests of actors, shows that norms can shape identity so that parts will be in line with standards as well as state policies. This makes constructivists more lenient towards national interests because they believe that if identity changes, everything will also change, both in the parts of the state and changes in the normative structure (Rachmawati, 2018, pp. 28-29).

\section{RESULTS AND DISCUSSION}

\section{China's Implementation of Panda Diplomacy}

\section{History of Panda Diplomacy Implementation}

China uses symbolic power through animals to build strength, image, and identity, and several animals have been chosen as symbols to aim at the world. China chose this animal because it has a background related to aspects of China's history and culture. In the past, ethnic Chinese has known as ethnic dragon descendants. The 
dragon is used as a symbol because based on culture, the dragon is a symbol of good luck and a symbol of longevity. This belief in this symbol can be found in traditional Chinese architecture where people make dragon carvings on the window frames of houses. After the establishment of the People's Republic of China under the Chinese Communist Party, the country formed a new animal symbol that considers to have historical relevance and a character of Chinese culture at home and internationally, the animal is the panda. Panda is also used as a symbol to show the gentleness of today's China, compared to the ancient 'red dragon' sign, which shows China as an aggressive country (Zeng, 2017).

China has a rich culture and history as well as a variety of unique symbols, what people think of when they hear the word 'China' is the great wall of China, the red and yellow colours, the dragon, and the cute black and white animal, the panda. This indicates that symbolic power influences the perception of the wider community. Panda was chosen as a tool of China's diplomacy because pandas are animals that are attached to the culture and are a national treasure for China (Chinasage, 2019). In the news, it said that the China people believe that the panda is a symbol of peace, friendship, and good fortune, this has also reflected in the black and white colours which are also a natural form of yin and yang mythology. This black and white colour depicts the calm nature of the panda in creating peace and harmony in life. The visual of a panda express tenderness, affection, and will not bring sadness. The Chinese state gives a symbol to the panda so that the panda becomes an icon to remember China (Muzakki, 2017).

The aim of diplomacy is actually to improve the reputation and position of a country, and this goal can be achieved through several means or forms of diplomacy, one of which is through animal diplomacy. Panda has used as a diplomatic tool to strengthen China's soft power and show that China is a strategic partner in establishing cooperative relations, both in the social, economic, animal conservation, and environmental fields to meet natural resources. This diplomacy has indeed carried out with a bilateral cooperation pattern which refers to political and cultural relations involving two countries (Djelantik, 2008, p. 85).

A journal article written by Hartig said that pandas also have good visuals. The visual identity of animals is essential in determining the success of diplomacy because it can change the minds and hearts of others. The more attractive the animals eat, the more successful the diplomacy with animals is. Konrad Lorenz also said that visual identity could be described through a child's schema, where the characteristic features of young children evoke feelings of care and protection; this is due to instinct. According to Lorenz, animals such as dogs, cats, and pandas have baby-like traits that make them cute in the perception of others. Also characterized 
by a high and prominent forehead, a head with a brain as large as the face, slanted eyes, round cheeks, and short limbs are stimuli that cause a feeling of tenderness. These traits make the giant panda a suitable mammal for animal diplomacy. Lorenz features in the panda, plus a round face and black eyes that give him a "cuddly" appearance and show that the panda is like a child which evokes overall empathy for cuddling and protection. This heart's sense is the subconscious' result mind through the visual of the panda, with the panda can attract and attract the attention of the audience effectively, given the charm and charisma of pandas is so deep, regardless of where the panda comes. Panda diplomacy can be said to be successful because it has met the requirements; namely, there is a visual identity of animals and their natural distribution. This will increase China's publicity on the broader community (Hartig, 2013, pp. 54-55).

Panda diplomacy has carried out since ancient times, namely during the Tang Dynasty in 624-705 BC. Empress Wu Zetian sent a pair of pandas and seventy panda skins to Japan as a form of state gift. Panda's diplomacy at that time was still in the form of state gifts given to other countries who had visited. This diplomacy shows that panda is a valuable animal since a thousand years ago (Hartig, 2013, p. 60). During the Tang dynasty, relations between China and Japan developed rapidly, because China was in its heyday. China could gather experts and hundreds of thousands of soldiers to fight the nomadic forces that controlled deep Asia and the silk route, and this made its territory so vast that China's political hegemony was influential in neighbouring countries such as Japan, Korea, and Vietnam. As well as Chinese culture at that time continued to develop and become a mature culture, this period also produced many famous historical poets, painters, and literature. The Tang dynasty also fostered artistic innovation in printing or wood carving. Besides that, the closeness of China and Japan was also because Wu Zetian, the woman who first led China, had a desire to spread Buddhism as China's ideology at that time. Therefore, it caused many scholars and priests from Japan to come to China to study (ShinonSam, 2018).

For the Panda Diplomacy of the modern era, the first stage, which was started in the 1950s, carrying out the Panda Diplomacy was Mao Zedong's strategy. The 1950s was a year of ideological warfare between America and the Soviet Union, and Mao saw an opportunity to introduce China to these conditions. By opening itself up to these two powers, China hopes that America and the Soviet Union will see that another force can balance the two. However, when under Mao's leadership, China only sent pandas to the Soviet Union in 1957, this was done because Mao only wanted to have cooperative relations with friendly countries that had the same ideology (Hartig, 2013, p. 60). 
In 1979 Deng Xiaoping overthrew Mao Zedong's military rule with his neocapitalist powers. Since then, the orientation has changed; the Chinese communist party has conducted trade neo-liberalization through investment from transnational companies, carrying out global financial activities (Qomara, 2015, p. 32). Unlike before, Deng Xiaoping's leadership was more open in that Deng sought to reform China's economy to make China a country that was open both politically and economically. His open-door policy resulted in environmental diplomacy. In 1979, Deng Xiaoping signed an agreement with the World Wildlife Fund, which aimed to establish a conservation centre or protection for pandas (Shouqiut \& Voigts, 1993, p. 24). WWF is an organization that focuses on the protection of six main areas, namely forest, sea, freshwater, wildlife, food, and climate. Initially, WWF's function was only to save but change to solve the problems that threaten the six fields, due to the increasing number of factors that harm these six areas. In 1961 he panda was also used as an international logo at WWF because the black and white colour of the panda has its charm and is cute (WWF, 2019).

China only sent pandas to America in 1972 when Deng Xiaoping was leading China, who made the Open Door Policy. The panda shipment has made because President Nixon paid a visit to Beijing, and to return the favour China sent pandas. Nixon also replaced the panda shipment with an American musk cow, and this exchange symbolizes the strength of the bonds between nations. At that time, also pandas were made a gift by China to countries visiting China. Panda's diplomacy has proven to be able to thaw the relationship between the two, which had previously frozen their relationship (Islami, 2015).

Deliveries of pandas are becoming attractive to other countries and have led them to want to ship pandas from China. China certainly cannot fulfil the wishes of other countries, because the panda population is decreasing due to a large number of poaching of pandas. In this second phase, which began in the 1980s, China began to realize the scarcity of pandas and tightened its shipping. This scarcity made China change the Panda Diplomacy system by renting out. This panda rental is Deng Xiaoping's attempt to protect the panda population as a characteristic of China. Panda is leased for a while to the recipient country, only for about 100 to 200 days. Panda was made into exhibitions and travelled the city, this led to much criticism from animal activists and caused the system to experience a complete halt (Hartig, 2013, pp. 60-61). Deng Xiaoping also made pandas as the country's ambassador, so it is now known as Panda Diplomacy. Changes in Panda Diplomacy practice also follow changes in the time and political situation of China when establishing bilateral cooperative relations with other countries. This panda borrowing also means that China gives trust (guanxi) and loyalty to forge bilateral cooperation that 
exchanges national treasures to create a close relationship (Buckinghamn, David, \& Jepson, 2013, p. 263).

In the next stage, China was more selective in choosing recipient countries, and China used this Panda Diplomacy to build trust and establish international trade relations. China started to tighten the Panda Diplomacy system both in terms of terms and rental fees. China realizes that the panda as a national treasure is a precious animal and has business value. Therefore, there was a change in the system where Panda Diplomacy had not given to other countries as a pure intention but turned into a 'panda rental' program, and of course, there were business interests and other interests (Buckinghamn, David, \& Jepson, 2013, p. 266; Hartig, 2013, p. 58). As Henry Nicholls, author of "The Way Of The Panda" said, the benefits of the Panda Diplomacy system are enormous in financial terms. When there is a discussion about China's panda loans to other countries, it means that there are also other business agreements (Scotman, 2011).

China not only uses pandas as commercial transactions but also shows a form of disapproval of bilateral relations. China once threatened to take the pandas in America, and their relationship would be damaged if Obama had a meeting with the Dalai Lama. China also said that the panda shipments only made to zoos that had met the essential technical capacity and resources. There are cases where China postponed sending pandas to Europe due to the financial crisis that hit Europe, and new pandas had sent when the G20 Summit was able to resolve these problems (Zeng, 2017).

Countries that receive a shipment of pandas have deemed to have made a panda loan for a minimum period of 10 years and must pay the US \$ 1 million in rent per year to pay to the Chinese Wildlife Conservation Association. Even when these pandas succeeded in inbreeding, the panda cubs that were born belonged to China, all pandas outside the country belonged to China (Islami, 2015). However, when contracted pandas die from human error, the recipient country eats a $\$ 500,000$ fine. Also, receiving countries must comply with the rules in the Convention on International Trade in Endangered Species of Wild Fauna and Flora (CITES), which are international rules that have a positive impact on panda conservation and this agreement explains that China and the receiving country will only export pandas when this transaction has carried out. Yields positive protection for pandas.

China has high hopes for the recipient country that the zoo must get pandas to breed. For pandas' survival, China also sees that the destination countries for shipping must meet standards so that pandas can be cared for properly. Panda is the most expensive animal in terms of care, a panda can spend hundreds of dollars in a year which is five times that of an elephant, so the recipient country chosen by China 
must match the criteria. This is done because China, through Panda Diplomacy, tries to build and improve its image and relations with other countries that can supply China's needs, both natural resources and technology. The earthquake that occurred in Sichuan in 2008 which resulted in a decreased panda population and damaged facilities were the reason that rental fees could use to improve panda conservation facilities and conduct research on pandas (BBC, 2019).

\section{The Implementation of Panda Diplomacy in Xi Jinping's Period}

In 2013 Xi Jinping became president of China, after Xi Jinping's inauguration said the importance of cultural exchange to create a harmonious world. On another occasion, Xi Jinping also said that he would try to achieve the big dream of the Chinese nation, namely the Chinese dream. In the economic field, Xi Jinping will focus on sustainable development and scientific development that pays attention to resources and the environment. In political developments, Xi upheld the socialists by saying that all power belongs to the people. As for ecological development, Xi focuses on conserving resources and protecting the environment (Xinhua, 2012).

At the beginning of his leadership, Xi introduced the concept he created, namely the Community of Common Destiny (CCD). CCD has meaning where there is a group of individuals or nations who are interconnected and bound to each other because the same fate and also have interests in it. Xi explained that when giving a speech at the 70th UN General Assembly, CCD has five perspectives, namely political partnerships, economic development, security, cultural and environmental exchanges. Xi also said that they should build partnerships with other countries that they treat equally. China emphasizes the importance of creating security, mutual justice, promoting the innovative and open development, and enhancing civilizational exchanges, and building ecosystems that care for nature. Diplomats and leaders in China perceive this concept as an expression of interest and fate between China and other countries so that they must overcome together to face challenges in a partnership that they can develop together (Zhang, 2018, pp. 196198).

Furthermore, according to Zhang, $\mathrm{CCD}$ also aims to convey that China wants to maintain the status quo of the international order and has no other intention. As a country that has experienced an increase in economic development and made China an influential nation, Cian emphasized that when there are new powers present in the international order, they must threat the same as other developed countries. China wants to increase its strength and role in global affairs, and China wants to bring about peaceful change and maintain the status quo. 
This is what makes Xi Jinping bring China to a country that promotes soft diplomacy. According to him, through international communication, China can strengthen soft diplomacy and can build a good image to the international community by showing China's ability in creativity and credibility. Panda's diplomacy has expected to change people's perceptions of China for the better. The Oxford study says that Panda Diplomacy carried out by China is a construction effort and is included in the Guanxi concept, namely trust in strengthening trade relations characterized by trust, loyalty, and longevity (Muzakki, 2017).

Panda diplomacy in the Xi Jinping era was increasingly carry out on the background of the big earthquake in Sichuan in 2008. Eighty-eight per cent of the panda population in China is in Sichuan, and the rest are in the surrounding area. So an earthquake measuring 7.8 on the Richter scale devastated Sichuan and resulted in a decline in the panda population and caused the habitat of wild pandas to be destroyed by 67 per cent. The destruction of this habitat only leaves a panda population of 60 pandas still alive. Thus, to protect the panda habitat that has declined drastically, China has again changed its Panda Diplomacy policy. Where, the Panda Diplomacy goal is to breed and find new habitats for the remaining pandas (Riffi, 2017).

Although the objectives of this diplomacy had changed, the Panda Diplomacy system was still the same, namely the structure of leases, fines, and periods. Many questions arise about the Panda Diplomacy that countries want, why zoos around the world are competing for a pair of pandas, and potential recipient countries have been negotiating for years to get a couple of pandas. Besides, the consequences of receiving countries are also hazardous, where the income generated by the zoo is not proportional to the expenditure. According to Nicholls, the value contained in the panda is not just identity but symbolic importance invested in the panda animal. This panda animal also opens a new understanding of panda conservation in China and globally (Hartig, 2013, p. 63).

Xi Jinping's Panda Diplomacy Policy received support from the China community, and this can be seen from the CGTN news which discussed the pros and cons of Panda Diplomacy. The two sources in the report said that pandas are attractive animals, can be good friends and are unique, and are native to China. Through Panda Diplomacy, which means helping to conserve pandas in a sophisticated way, allowing many people in the world to be able to see this extraordinary animal. But this is also a challenge for China, where China must conserve pandas in its own country but also encourage other countries to take part in the conservation of pandas. This system is not the best, but it has succeeded in increasing the panda population, and this tradition must maintain. Panda's diplomacy is also useful in 
raising human awareness of protecting pandas, because the China government, the scientific research sector, and China society also pay great attention to pandas. However, the welfare of the pandas on the long journey to other countries has neglected, and it fears that it will cause difficulties and stress for the pandas. The rent is limited because the money has invested in protecting the pandas as a whole. The ideal model, according to them, is when other countries sponsor the conservation of pandas in their natural habitat (CGTN, 2017).

\section{Implementation of Panda Diplomacy in Indonesia and Implications of Bilateral Cooperation of Both Countries}

Panda diplomacy in Indonesia was initiated in 2010 when Susilo Bambang Yudhoyono became president of Indonesia, namely on the $60^{\text {th }}$ day of the celebration of "Friendship of Indonesia and China" (Berty, 2017). take by China to carry out Panda Diplomacy and make Indonesia a comprehensive strategic partner, because Indonesia is an influential country in ASEAN and through Indonesia, China can expand its national interests in ASEAN. This is following the constructivist view, where the State like humans is an actor in international relations which has attributes in it such as rationality, identity, interests, and beliefs, as well as the State. This attribute will affect how the actor acts. Wendt emphasized that "Actors use ideas to construct relationships and material reality. So ideas precede negotiations and interpret history to make relationships either conflictual or cooperative". The State will take policies by weighing excellent or bad (the logic of appropriateness) rather than profit or loss (the sense of consequences), this shows that the State is not an actor who is concerned with personal interests (self-help) (Rosyidin, 2015, p. 27)

On September 28, 2017, Panda diplomacy was just implemented in Indonesia, marked by the sending of pandas named Cai Tao and Hu Chun to Jakarta and being received directly by President Joko Widodo, where this indicates good relations and cooperation between China and Indonesia (Berty, 2017). Before that, Indonesia and China had conducted a Memorandum of Understanding on Panda Diplomacy on August 1, 2016, and signed by Tachrir Fathoni as a representative of the Ministry of Environment and Forestry of the Republic of Indonesia, and Chen Fengxue who represented the state forestry agency of the People's Republic of China. In the MoU, China and Indonesia acknowledge that the cooperation carried out by both is friendly and strengthens collaboration and exchanges in the field of wildlife conservation, especially endangered species between the two countries. As well as acknowledging that the panda conservation cooperation initiated by the China Wildlife Conservation Association and the Indonesian safari park is a partner that promotes friendly relations between Indonesia and China (Ministry of Foreign 
Affairs, 2016). The regulations contained in the MoU must obey for the smooth running of cooperation projects between countries. Constructivists also see that the state will respect existing norms and rules so that they are considered reasonable and can be trusted by other countries. This shows that the international community recognizes national interests. Constructivists see that state loss is a loss of trust caused by previous inappropriate actions (Rosyidin, 2015, p. 27).

Following the implementation of Panda Diplomacy in Indonesia, China Prime Minister Liu Yandong and several other ministers visited Indonesia in November to attend Indonesian and Chinese cultural arts performances. The performances held in Jakarta have the aim of introducing arts to one another and showing the local wisdom of each country. The two parties then agreed on a plan to establish a bilateral dialogue mechanism between community relations at the coordinating ministerial level (Okezone, 2017). In the same year, Indonesia also hosted the 3 rd High-Level Meeting in the field of relations between the Indonesian and Chinese people, Liu Yandong said that this was an excellent step to encourage joint development that began in 2015. The mechanism was already in place, and now cooperation was increasingly expanding on a large scale as well, community participation is also active, this mechanism is a forum for increasing collaboration, increasing the level and influence of community exchanges by laying a more robust social basis for the strategic partnership of China and Indonesia (China Embassy, 2017).

The relationship between the people is getting closer has been proven by cultural activities; China is working with Jakarta to organize an exhibition of archives of social relations between Sino-Indonesians in Beijing. In the same year, the 2017 Chinese and Indonesian cultural festival activities had also held in various cities in Indonesia, such as Malang and Jakarta. In September 2018, the Peking opera Binta Chu Lanlan collaborated with an Indonesian company to create a cultural event to support the BRI Belt and Road Initiative. Furthermore, to keep the exchange of cultural information to develop, several institutions built. As Bali became the city chosen as the first cultural exchange centre forum under BRI, it had formed between the Chinese consulates, namely Peking University and Udayana University. Furthermore, 36 art teachers from various provinces in Indonesia were invited by China in early April 2019. These guests attended education and cultural communication training in which there were lessons about Chinese culture, including opera, traditional music, and calligraphy at the China Conservatory of Music (CCOM ) in Beijing. The activities that have carried out symbolize that the foothold of Chinese culture is developing in Indonesia (Rakhmat, 2019). 
Also, since Jokowi's Panda Diplomacy was more open with China, President Joko Widodo signed presidential regulation No. 20 of 2018 on the use of labour. Indonesia also ratified the agreement with the China government regarding cultural cooperation (Agreement Between the Government of the Republic of Indonesia and the Government of the People's Republic of China on Cultural Cooperation) which is stated in presidential regulation No. 57 of 2018. It has written that Indonesia and China want to strengthen, improve, and develop intergovernmental relations in the more strategic cultural field and the need for cooperation in the cultural field. Given that Indonesia previously signed a cooperation agreement in the cultural sector with China in 2001. For this cultural cooperation to carry out, it is necessary to endorse (BPK, 2018).

November 2019 Indonesia hosted the 12th Asia-China People to People Friendship Organization (CACPPFO) Conference for the second time. According to the Chairperson of the Indonesia-China Economic, Social and Cultural Cooperation (LIC), Indonesia is the host of CACPPFO for the second time, where 2008 is the first year. LIC is the agency responsible for organizing CACPPFO because LIC is an institution founded in 1992 as a symbol of the thawing of diplomatic relations between Indonesia and China. This congress aims to create attitudes, activities, and programs to promote social ties in 10 ASEAN countries with China (Setnasasean, 2019).

The conference was held in Bandung and attended by 11 countries, namely China, Indonesia, Singapore, Thailand, Laos, Cambodia, the Philippines, Malaysia, Brunei Darussalam, Myanmar, and Vietnam. It had produced five agreements aimed at strengthening economic, socio-cultural cooperation between China and ASEAN. First, CACPPFO agreed to run an exchange program for experts and scholarship recipients in the fields of agriculture, culinary, literature, design, environmental protection, energy, and digital. Second, Student exchanges are carried out through short-term homestay projects, aiming to increase knowledge of cultural values from both parties and train young generations and leaders to understand and respect each culture. Third, The 'Belt and Road Initiative' \& Master Plan on ASEAN Connectivity 2025 (MPAC) program will be supported by the leaders of ASEAN countries, and this is following the statement of the 22nd China-ASEAN Leaders Summit in Bangkok. Fourth, CACPPFO supports the exchange and cooperation of local governments between countries through sister cities and sister provinces. Fifth, The latest results state that China-ASEAN will eradicate and prevent hoax news on social media and mass media because hoax news has a bad impact on every country. The essence of this conference is that China and ASEAN countries will maintain peace, security, and stability in ASEAN and China (Ika, 2019). 
Before this agreement made, Indonesia and China had agreed, Jusuf Kalla's visit to meet Xi Jinping in April 2019 resulted in a commitment to cooperation in the fields of trade, investment, and education. The Belt Road Initiative (BRI) project made by China has several principles, one of which is that China must make partnerships and unite the development of each country by paying attention to the environment because this project will produce new progress and tangible results. Jusuf Kalla said that Indonesia would help China in the BRI project and was ready to become a partner. Besides, Xi also sees Indonesia as a country that has an essential position in the maritime silk route development plan, so seeing the deficit in Indonesia Xi promised JK to import more Indonesian products such as CPO and also increase the scholarship quota for Indonesian students who want to study. In China (Asmara, 2019).

Indonesia's support and cooperation between the two are further explained in the MoU "Joint Promotion Cooperation within the framework of the Vision of the World Maritime Axis and the Silk Road Economic Belt and the 21st Century Maritime Silk Road Initiative" signed in 2018 in Beijing. In this MoU, Indonesia and China are referred to as parties that jointly strengthen comprehensive strategic partnerships and deepen bilateral cooperation. The purpose of the collaboration is to achieve mutually beneficial mutual sustainable development goals, as well as to enhance political, socio-cultural relations, security cooperation, and community exchanges and both must promote regional ties. Indonesia and China are cooperating in the field of infrastructure connectivity exchange, expanding two-way investment and trade, encouraging each financial institution to provide cost and service support for production, investment, and trade cooperation, improving relations between people through the education sector, culture, health, tourism, and public welfare to strengthen public opinion in supporting bilateral cooperation and always discuss regularly regarding development strategies, planning, and policies (Ministry of Foreign Affairs, 2018).

In realizing community exchange cooperation in the field of education, Xi Jinping made a policy by increasing the scholarship quota for Indonesian students in China. China issued a total of 197 full scholarships for Indonesia both undergraduate and postgraduate degrees, and this is very different from 2015, where China only provided a scholarship quota of 15. So that in 2018 according to Chinese government data it shows that Indonesian students in China are around 14,000, according to the Chinese Service Center for Scholarly Exchange (CSCSE) of Indonesian students in China has increased by $10 \%$ annually since 2010. Meanwhile, the number of China students in Indonesia in 2018 was 720 students. Although the anti-China sentiment is still felt in Indonesia, China is very open, and warmly welcomes Indonesian students (Muhaimin, 2018). 
The increase in China scholarships in Indonesia also occurred in 2019, as many as 820 Indonesian citizens received scholarships from the Chinese government, 380 were undergraduate to doctoral students, 440 students in vocational institutions, and 1,100 Indonesian citizens received short course programs. According to Atdikbud, this addition made the number of Indonesian students in China increase to 15,780 . Seeing this, the Indonesian government gave feedback to China, namely adding Indonesian Language Study Programs at 19 universities and opening Indonesian research centres (IRC) in 15 universities in China (Wardani, 2020). Students both in China and in Indonesia have a vital role to play in disseminating the culture of their respective countries. Samuel Huntington said that urban intellectuals were an essential part of pushing for political change or reform. As a group of people who occupy school to a college education has gone through the process of socialization, where they have different backgrounds and carry out daily campus activities, from these activities and interactions that will result in cultural exchanges.

According to the China Ambassador at that time, the comprehensive strategic partnership cooperation between China and Indonesia continued to increase, as indicated by the existence of practical collaboration and many exchanges in various fields that were getting deeper. So that increased political trust, mutual respect, understanding, and support from both parties will produce a significant contribution to regional peace, prosperity, stability, and growth (Yuliangningsih, 2019). The implementation of Panda Diplomacy in Indonesia also strongly supports China's interests in the Malacca Strait. Through its closeness to Indonesia, China will undoubtedly be able to solve the Malacca Dilemma problem a little, because as a coastal state in the Malacca Straits, of course, Indonesia's existence is a strategic partner for China. This closeness will reduce China's concern about the problems that occur with the effort to import petroleum through the Malacca Strait.

\section{Implementation of Panda Diplomacy in Indonesia: A Constructivist Perspective Review}

Constructivists emphasize that social reality is the result of construction, relationships carried out by humans and international relations are the result of thoughts and ideas and not from the strength or material conditions they have (Jackson \& Sorensen, 2013, p. 370). Alexander Wendt proves this through arguments made to show that society and politics have built from social conditions in anarchy. This argument has based on two principles of constructivism inspired by interpretive sociology, namely symbolic interactionism. First, individuals act because there is meaning that other objects or actors have for them. Second, the definition contained in these objects and actors will continue to develop in social 
interactions (Zehfuss, 2002, p. 14). Herbert Blummer (1900-1987) who is a figure in the theory of symbolic interaction explained that there is a third assumption of this theory, namely that the meaning will also change when it goes through the interpretation process (Rosyidin, 2015, p. 18). Symbolic interactions are formed from each individual who has their respective roles in making relationships, and these interactions result in reactions to one another and an understanding of the behaviour of others. This learning process leads to identities' formation, and each identity refers to the role of oneself and the functions of others. The repeated interactions make the identity created will become an appreciation and belief (Wendt, 1999, p. 342).

China carries out this symbolic interaction through Panda Diplomacy, and Panda is not just a symbol used to build an excellent Chinese perspective and identity in the world. Panda can be seen from many aspects as a source of Chinese soft power, where Panda has a role to improve China's image and views of other countries. The relationship between pandas and China is inseparable, to maintain this relationship, China will give Chinese names to pandas, and China also has an influence on the receiving countries in terms of establishing zoos. This will affect the perspective of visitors, where when they see pandas they will associate pandas with China, in contrast to other animals that come from other specific countries (Hartig, 2013, p. $69)$.

In promoting cooperative relations with other countries, China uses a symbol that represents its national interests. Chinese traditional culture used to use the dragon as a symbol of the country to show China as a country that is rising and has extraordinary enthusiasm. Western countries see the rise of China as a threat that strikes for them according to the dragon symbol used by China. This happens because of different conceptions of meaning, Professor Guan Shijie at the Peking University School of Journalism and Communication stated that the word "loong" actually means a long animal symbolizing China's success. But to the west, the word means a fire beast with a long neck that emits fire with every breath and wings which means aggression. Wu Youfu, chairman of the Shanghai International Studies board, also added that a dragon is a form of solidarity, courage, and enthusiasm for Chinese people. But still, there is distrust from western countries. Besides, many claims that the dragon is not suitable to be a symbol of China because the dragon is not a real animal in this world and the dragon is a traditional symbol of Chinese culture which is still closely related to the imperial autocracy, and it is feared that it will harm the development of democratic politics (Bin, 2007).

This has strengthened the China government to use the panda as a diplomatic tool apart from the panda being a real animal, and pandas also have a gentle nature 
compared to dragons. Panda's diplomacy has received the spotlight from the local and international press because, in the rental contract process, state officials signed an agreement between the two countries. This activity is precisely what the China government wants to show so that the wider the media that covers it, the more people will know about the cute panda, and also the focus of the community is only on China as their home country which makes China's image better (Hartig, 2013, pp. 56-57).

Based on this, the authors see that China is carrying out Panda Diplomacy to improve its image and identity to achieve national interests, what China has done is the result of the thoughts and ideas of the China government. The China government realizes that their country needs another country to succeed in its national interests and this can be achieved when China has a right image and identity, which creates a sense of trust from other countries. This national interest will undoubtedly bear fruit along with the change of China leaders because each individual has a different idea, idea or discourse, and political direction. This ideational view focuses on intersubjective beliefs such as ideas, conceptions, and assumptions. This idea must be disseminated to be useful, ideas which are the result of mental constructs held by individuals as well as other groups, where actors have different beliefs, principles, and attitudes, which will later become orientations for behaviour and policies (Jackson \& Sorensen, 2013, p. 373).

Alexander Wendt believes that the primary unit of analysis in $\mathrm{HI}$ is the state, and the nature of this state can change due to changes that occur in international, individual, economic, and political structures. Thus the national interest of a country is also temporary, meaning that the national interest is formed, transformed, and adapts to the international political system. The national interest results from social construction following the situation and conditions of the. So that national interests are formed from interactions between countries as political units and state structures in international politics. Constructivists through logic believe that the national interest is not something that is given and fixed, but will continue to change, this is because the structures contained therein are formed from shared ideas (Wendt, 1999, pp. 189-190).

Although many countries have received Panda Diplomacy from China, China will continue to interact with other countries to disseminate and maintain the country's identity as a friendly country and capable of being a strategic partner. As a country selected for Panda Diplomacy, Indonesia is one of the countries that China considers a friend or strategic partner. Liu Jianchou, as the Chinese Ambassador to Indonesia in 2013, argued that China and Indonesia entered into a partnership because of the result of a close bilateral relationship. The increase of the strategic 
partnership to become a comprehensive strategic partnership shows that the two of them will be connected in the long term because of this relationship base on mutual trust. There is also an opinion from former officials of the Indonesian Ministry of Foreign Affairs that the Ministry of Foreign Affairs of China needs a symbol that can represent a strong relationship with Indonesia, and this partnership means that Indonesia is a close friend country (Priyandita, 2019, p. 17).

The relationship between China and Indonesia, according to neorealists, is impossible because the views between neorealists are materialist views. In contrast to the constructivists, namely the ideational theory (Jackson \& Sorensen, 2013, p. 372). Neorealists see international relations as determined by the existing material structure. Constructivism sees it from the other side, namely through the ideas that will shape international relations. This makes the perceptions of international actors influence the actions or determine the patterns of interactions that will occur. When realists see the state's efforts in increasing military power make other countries fearful, the term "security dilemma". So the response of neighbouring countries should increase their security strength, but the reaction of neighbouring countries is just average. Constructivists answer that the response issued depends on the perception of the country in assessing whether it is a threat or not (Rosyidin, 2015, p. 18).

Under President Jokowi, Indonesia saw China as a friend and not a threat to Indonesia, and this can be seen from Indonesia signing the MoU on strategic partnerships. China also makes Indonesia a comprehensive strategic alliance because Indonesia is an influential country in ASEAN, through Indonesia, China can make it easier to enter ASEAN. Finnemore and Wendt said that in shaping a country's identity, an international environment is needed (Jackson \& Sorensen, 2013, pp. 381-382). In international relations, the state will try to build an identity to get recognition from other actors. However, there is also a constructivist perspective that sees the domestic environment also contributes to the formation of state identity. Not all international environmental norms are accepted and have different effects in each country, so domestic factors are responsible for this. According to constructivists, identity and interests are interactions that are carried out with each other and create a structure of identity and parts. With the interaction between countries, identities, and interests can be known. Finnemore also argues that international organizations that put forward international norms can influence national guidelines; countries will make these norms guide in making their national policies. Alistair Johnston also conveyed this, that international standards in international relations can change state behaviour. 
The identity of a country describes the trends and actions of the state, and constructivists see that identity is fundamental in life. The state will be chaotic without originality, and the world fill with uncertainty and no solution, this condition is more dangerous than anarchy. Identity has the function of telling you who to others (Hopf, 1998, p.175). There are four kinds of identity, according to Wendt in international relations. First, personal identity (corporate identity), which is an attribute of the state that makes a country different from other countries, and the state has an individual identity that other countries do not have. Each country has the characteristics that differentiate it from other countries, both in terms of territory, national symbol, national anthem, nationalism, and others. Other countries do not own pandas, and this makes China different from other countries. China people's belief in pandas as a form of yin and yang means that pandas are animals that bring peace, so this helps China in building an image and identity. Personal identity does not need a significant other to differentiate it from other countries. All countries have an identity like this, giving rise to the interests that all countries want, such as the desire for physical security and social identity, the desire to be recognized, respected, and achieve prosperity (Rosyidin, 2015, pp. 50-51).

Second, type identity, which is an identity that classifies a country into specific categories; this depends on the inherent characteristics of the country. This type of identity is known when there is international interaction, and there are intrinsic attributes such as the political ideology of the country (Rosyidin, 2015, p. 51). This identity can be seen from China's ideology, namely communism, which has made China known as a communist state. Starting when China led by Mao Zedong and founded the China Communist Party, the establishment of this party had the aim of taking back China's rights which had been occupied by the colonial government. After the Opium war around 1840, western imperialism entered China and made China enter a "century of humiliation" in which China's sovereign territory became divided and colonized by colonialism. The insistence created by western imperialism pushed Mao and Chinese society to rise again to fight against colonialism. This resistance successfully carried out where China managed to regain the territory occupied by the colony (Nufus, 2014, p. 46).

The significant steps taken by Mao made China develop faster until now China has evolved and has become the second-largest economy in the world. However, the rise of China-made other countries afraid of China's domination, this was also motivated by the meaning of communism brought by Mao Zedong. During his leadership, Mao also gave strict and authoritarian rules, whereby all books or arts that did not support Communism would destroy, and those who opposed them would be killed (BBC, 2019). This reason also makes the Indonesian people still 
have anti-China sentiments because people consider that the cooperation between China and Indonesia is China's way to dominate Indonesia.

Third, role identity, which is an identity that sees the state's position in international relations and concerning the state's responsibilities when faced with specific situations. This identity requires an intersubjective to determine the status of the actor and is needed by other countries as a significant other as a comparison (Rosyidin, 2015, p. 53). Xi Jinping continued the concept of Deng Xiaoping's revival in which China hopes that the next generation will be happy, create strength and build a spirit of nationalism, according to Xi's China dream not only benefits the China people but is also in line with the objective of the international community. This is what makes him want to rebuild the maritime silk route again, because, with the silk route, China can regain the pride and glory of China in the past and revive the economy of the surrounding countries. Xi emphasized this when he visited Kazakhstan and Indonesia in 2013, and it was not without reason that Xi chose to convey his ideas in the two countries. Kazakhstan is a connecting country between China and countries in Central Asia which have rich natural resources. Meanwhile, Indonesia had chosen because of its geographical location that coincides with the strategic route of international waters (Nufus, 2014, pp. 49-52). In making policies and determining the direction of development, Xi Jinping also views matters of domestic and international interests and maintains the principle of peaceful development; therefore Panda Diplomacy policy is also one way to achieve Xi Jinping's interests.

Fourth, collective identity, namely identity, is formed when actors have the same interests, so that these actors will take action together (Rosyidin, 2015, p. 51). Jusuf Kalla's visit to China to discuss cooperation in various fields made Jusuf Kalla say that Indonesia and China have the same interests, namely infrastructure development. China is a country with extensive industry, so it requires a large market as well, which makes China have to improve communication to every nation and Indonesia is a large market for China. It is this common interest that makes them agree to work together on the Belt Road Initiative project (VIVA, 2019). Besides, the Panda diplomacy carried out by the two indicated that they wanted to carry out cultural exchanges to strengthen their relationship. Similarly, the Panda diplomacy carried out by the two suggests that they are willing to carry out cultural exchanges to enhance their relationship. Sun Weide as the Consular of the Chinese Embassy to Indonesia said that Cai Tao and Hu Chun came to a country with thousands of islands to become a bridge of friendship for China and Indonesia, as well as a new momentum in promoting cultural cooperation between the two countries (Detik, 2017). 
Constructivists and neorealism have the same idea of interest, and they assume that claim implies choice. Realists say that every country has the same priority interests; these interests might occur if interests are the result of social practices that shape actors and structures. However, according to constructivists, interests are a product of multiple identities and identities; the identities formed imply a different set of interests. Social practices that shape identity will generate claims consistent with social rules and structures, and constructivist logic breaks the notion that curiosity is a gift (Hopf, 1998, p. 176).

Looking at the constructivist view, the writer argues that China carrying out Panda Diplomacy to Indonesia is also one of China's efforts to carry out its interests in the South China Sea and wants to cover up Natuna's problems, as well as the Malacca Dilemma problem because this problem has quite an impact on China's aggressive identity. This makes China have to rebuild a positive identity and perception in the eyes of the international community. Constructivists see that identity is impermanent, and it will change according to the meaning of the actors in the interaction. So that as much as possible, the actors must maintain their attitude in interacting to keep the identity they want. In a thesis written by Samuel P. Huntington, he states that the post-cold war world conflict is no longer ideological, but in the form of civilizational conflicts related to identities, culture, and culture. As underlining, that identity has a role as a cause of conflict and cooperation in world politics at the end of the twentieth century. Politics is not one way to achieve interests but also in introducing and maintaining identity. We will know ourselves when we know "who is not us" beside us, and this can be known through "whom we are dealing with" (Rosyidin, 2015, p. 45). Intersubjective can also influence behaviour in comparison to material structures. Through interacting actors will create collective meaning and identity. This identity is stable because there is an understanding of specific roles and desires in oneself. In the process of conceptualizing a situation, identity is the basis for attracting interest, and identity needs to be developed and maintained in interactions with other people. When identity guides them in taking action, they also determine the form of anarchy that will occur (Guzzini \& Leander, 2006, p. 94).

Based on this, constructivists see that China has succeeded in using pandas to build a better identity and image. This has evidenced by the number of countries that want them to become recipient countries of Panda Diplomacy, even though they know the consequences or rules that they must obey when becoming a Panda receiving country. An example is Canada which has waited for Panda Diplomacy for up to 40 years (Islami, 2015). The success of China in building an identity as a friendly country, a strategic partner can be seen from the number of MoU ratifications by President Joko Widodo and the policies of the Joko Widodo 
Government that make it easier for China's access to Indonesia. It can also say that Panda's diplomacy is part of China's cultural diplomacy and image. A different way of making Panda's diplomacy does not look like ordinary diplomacy, where this strategic practice puts its practice outside the framework, even so, the Panda has the right steps for the long term and increases China's attractiveness in the eyes of the public and the host country.

Constructivism assumes that identity has the potential to become part of the constitutive practice of the state, which makes this identity capable of producing action at home and abroad. With originality, there is an advantage to politics, namely the emergence of differences between countries. In one country alone, there are many different actors or actors in world politics, and each country has different views and actions towards other countries, that identity determines this. Therefore, a different pattern of behaviour needs between groups of countries with different identities and interests. Identity has more meaning than a mere label, with this China will try to invite each country to understand other countries in terms of their nature, motives, interests, actions, attitudes, and roles in politics (Hopf, 1998, p. 193).

This is what Xi Jinping did, the implementation of China's Panda Diplomacy in Indonesia, making it easier for China to create cooperation and policies between the two. After Panda Diplomacy had carried out, Xi also focused more on community development or people-to-people relations between China and Indonesia. Individuals have an essential role to play in maintaining this Chinese identity, a policy made by Xi Jinping by increasing cultural activities in Indonesia and increasing the scholarship quota for Indonesian students in China. This aims to increase knowledge of Chinese culture to the public, Indonesian students in China will, of course, learn Chinese culture. Through them, Xi Jinping hopes that Chinese culture can be better known and accepted; there are still many opinions that China is a military, severe, and uncooperative country. But on the contrary, with diplomacy, Panda China will be known as a friendly country with good intentions.

Tempo conducted a survey.co shows that Indonesians still have difficulty understanding the basic principles of equality in political rights and democracy. The director of the Jakarta Institute of Conflict Policy Analysis (IPAC) said that the majority of Indonesians do not want to understand the basic principles of democracy, which are political equality and justice or equal rights, be it race, ethnicity, religion, or sexual orientation. Thirty-three per cent of them believed that Chinese culture could not be in line with Indonesian culture, thirty-two per cent saw that the Chinese minority still clung to their ancestors, namely China, and 
thought that the Chinese were greedy and ambitious and this was as much as 35 per cent who believed (Tempo, 2019).

The author also believes that the reason China is now more focused on intercommunity relations is that there is still much anti-China sentiment in Indonesian society for domestic problems such as economy and politics. It is undeniable that there is always an anti-China sentiment in Indonesia; however, this sentiment aim at domestic issues such as the economy, racial and communist stereotypes, and this has not stopped the efforts of the Indonesian people to go to China, and many continue their education there (Muhaimin, 2018 ). Therefore, the addition of the scholarship quota and the creation of cultural activities by Xi Jinping, are China's efforts so that slowly the Indonesian people can be more open to China and accept Chinese culture. Although the bilateral relations between China and Indonesia continue to improve and to maintain friendly relations between the two, China also needs the support and activeness of the community to learn from each other Chinese culture. In the Constructivist view, the State like humans, is an actor in international relations that has attributes in it such as rationality, identity, interests, and beliefs, as well as the State. This attribute will affect how the actor acts.

Besides, constructivism is a theory that changes the approach in international relations, if liberals and realists who see material and agent-centric matters are essential in international relations and the state is a given interest or does not have an inherent interest. Constructivists see that the state is not a shared interest because there are norms within the state, which makes the state inseparable from the social structure (Rachmawati, 2018, p. 28). The Chinese government is trying to convince the existing social system in Indonesia, and here it means the Indonesian people because Indonesian people have an essential role in making policy in Indonesia.

Hadiwinata (2017) states that constructivism has two main ideas in international relations and can see the relationship between China and Indonesia. First, material strength is not a structure that unites humankind but is determined by shared ideas. Second, shared ideas ascertain the identity and interests of actors rather than natural factors. Actors will act to do something not based on their motives, but actions have shaped by interactions between individuals in their surrounding environment, such as social, political, economic, cultural, and other structures. This illustrates that the social world is not Given, the laws of the social world cannot be determined from scientific research and explained through scientific theory because the social world is intersubjective (Hermawan, 2017, pp. 20-21). The relationship between China and Indonesia is the result of a shared understanding. Through Panda Diplomacy, the sense of trust between governments is increasing, 
and they think that the two are friends. With this assumption, they can take action, especially China, to achieve its national interests.

\section{CONCLUSIONS}

Xi Jinping said that a country that accepts Panda's diplomacy would be considered a friend by China and China made its position a strategic partner. Indonesia is a country chosen in Panda Diplomacy, and Xi sees Indonesia as a country whose priority is China in international affairs and a large country that influences the region. What is the constructivist view of seeing China Panda Diplomacy in Indonesia? First, Panda has used as a diplomatic tool and a symbol of friendship to build a better China image and identity. Here Constructivists see that Panda's diplomacy is a form of symbolic interaction. Second, in carrying out Panda Diplomacy, of course, the China government has thought of any strategies that can help them in smoothing their interests. So that Constructivists see this as an ideational view, namely a focus on intersubjective beliefs such as ideas, conceptions, and assumptions. Third, the identity built by China through Panda Diplomacy in Indonesia is not just a form of friendship. However, there are other interests that China wants to achieve through Indonesia. Constructivist logic says that claims are the result of identity, which means that identity forms to imply different interests, so that identity is multiple.

Furthermore, the China government realizes that there is still an anti-Chinese sentiment in Indonesia, and the China and Indonesia governments need support from the Indonesian people regarding their cooperation which makes Xi Jinping focus on cultural cooperation and relations between people. The state is not a given interest because there are norms within the state, which make the state inseparable from the social structure. That is why pandas are used as diplomacy tools because pandas can portray China as a peaceful and friendly country. Through this image, hopes that China's national interests will be achieved, such as China's interests in the Malacca Strait and the South China Sea.

Seeing this, the authors conclude that the Panda diplomacy carried out by China is quite successful, where the panda which uses as a symbol of friends can see in the increasingly close relationship between Indonesia and China and the amount of cooperation made by the two countries. However, there are also challenges faced by China, namely the Indonesian people themselves, because there is still an antiChina sentiment in Indonesia. Society is an essential element in the state in making policies, and community support is needed further to strengthen the mutually beneficial relationship between the two. 


\section{REFERENCES}

Adam, A. (2018, 10 22). Relasi Jokowi dan Cina dalam 4 Tahun Terakhir. Retrieved from Kompas.com: https://tirto.id/relasi-jokowi-dan-cina-dalam-4tahun-terakhir-c8iE

Andika, M. T., \& Aisyah, A. N. (2017). Analisis Politik Luar Negeri Indonesia-China di Era Presiden Joko Widodo: Benturan Kepentingan Ekonomi dan Kedaulatan? Indonesian Perspective, 2(2), 161-179.

Ansah, S. (2019, o6 29). Indonesia-Cina Kerja Sama Pertukaraan Data EksporImpor. Retrieved from RencongPost: https://rencongpost.com/indonesiacina-kerja-sama-pertukaraan-data-ekspor-impor/

Asmara, C. G. (2019, 04 26). Komitmen China untuk RI: Perbanyak Impor, Tambah Beasiswa! Retrieved from CNBC Indonesia: https://www.cnbcindonesia.com/news/20190426103903-469037/komitmen-china-untuk-ri-perbanyak-impor-tambah-beasiswa

Bin, Y. (2007, 01 4). Is the Dragon a Suitable Symbol for China? Retrieved from Beijing Review:

http://www.bjreview.com/forum/txt/200612/29/content_52225.htm

Bloom, W. (1990). Personal Identity, National Identity and International Relation. Cambridge : Press Syndicate of the University of Cambridge.

Buckinghamn, K. C., David, J. N., \& Jepson, P. (2013). Diplomats and Refugees: Panda Diplomacy, Soft "Cuddly" Power, and the New Trajectory in Panda Conservation. Environmental Practice, 15 (3), 262-270.

Djelantik, S. (2008). Diplomasi Antara Teori dan Politik. Yogyakarta: Graha Ilmu.

Fan, Y. (2000). A Classification of Chinese Culture. Emerald Insight, 7(2), 3-10.

Febriansyah, H. d. (2016). Tinjauan atas proses penyusunan laporan keungan pada Young Enterpreneur Academy Indonesia Bandug. Jurnal Riset Akuntansi, $8(2), 19-28$.

Guzzini, S., \& Leander, A. (2006). Constructivism and International Relations . New York: Routledge

Hartig, F. (2013). Panda Diplomacy: The Cutest Part of China's Public Diplomacy. The Hague Journal of Diplomacy, 8(1) , 49-78. 
Hermawan, Y. P. (2017). Transformasi dalam Studi Hubungan Internasional : Aktor, Isu dan Metodologi. Yogyakarta: Graha Ilmu.

Hopf, T. (1998). The Promise of Constructivism in International Relations Theory. International Security, 23(1), 171-200.

Huang, Y., \& Ding, S. (2006). Dragon's Underbelly: An Analysis of China's Soft power . Journal East Asia, 23(4), 22-44.

Jackson, R., \& Sorensen, G. (2013). Pengantar Studi Hubungan Internasional. New York: Oxford University Press.

Jatmika, S. (2016). Skripsi : Metodologi dan Romantiknya. Yogyakarta: Penerbit Samudra Biru.

Kartikasari, A. (2019). Indonesia's Image From China's Perspective on South China Sea Dispute (A Preliminary Study on China's Perception on Indonesia). Jurnal Politik Internasional, 21(2), 176-197.

Nye, J. (2008). Public Diplomacy and Soft power. The ANNALS of the American Academy, 616(1), 94-109

Onuf, N. G. (1989). World of Our Making : Rules and Rule in Social Theory and International Relations. Columbia: University oÍ South Carolina Press.

Priyandita, G. (2019). From Rivals To Partners: Constructing The Sino-Indonesian Strategic Partnership. Jurnal Politik Internasional, 21(1), 1-26.

Qomara, G. (2015). Kebangkitan Tiongkok dan Relevansinya terhadap Indonesia. Jurnal Hubungan Internasional, 8(2), 31-44.

Rachmawati, I. (2018). Konstruktivisme sebagai Pendekatan Alternatif dalam Hubungan Internasional. Paradigma, 5(2), 25-34.

Rahmadani, S. Kusmanto, H. \& Warjio. (2019). Strategi Cina menghadapi Malacca Dilemma dalam rangka Pengamanan Jalur Energy Cina di Selat Malaka. JUPIIS: Jurnal Pendidikan Ilmu-ilmu Sosial, 11 (1): 141-148.

Rijali, A. ( 2018). Analisis Data Kualitatif. Jurnal Alhadharah, 17(33), 81-95.

Rosyidin, M. (2015). The Power of Ideas : Konstruktivisme dalam studi hubungan internasional. Yogyakarta: Tiara Wacana. 
Setiawan, S. (2012). ASEAN-China FTA: Dampaknya Terhadap Ekspor Indnesia dan Cina. Buletin Ilmiah Litbang Perdagangan, 6(2), 130-150.

Shouqiu, V. (1993). The Development Of China's Environmental Diplomacy. Pacific Rim Law dan Policy Journal, 3(1), 19-24.

Soesilowati, S. (2015). Diplomasi Soft power Indonesia melalui Atase Pendidikan dan Kebudayaan . Global \& Strategis, 9(2), 203-308.

Sriyanto, N. (2018). Global Maritime Fulcrum, Indonesia-China Growing Relations, and Indonesia's Middlepowermanship In The East Asia Region. Journal Kajian Wilayah, 9(1), 1-19.

Suryadi, D. U. (2017, Hal 159-161). Dasar-Dasar Hubungan Internasional. Depok: Prenadamedia Group.

Syahrial, M. (2018). Peran Direktorat Jenderal Bea dan Cukai dalam Mencegah Penyelundupan Sabu Lintas Negara di Pos Lintas Batas Negara di Kecamatan Entikong, Kabupaten Sanggau, Provinsi Kalimantan Barat. Journal of International Relations, 4(3), 489-498.

Uemura, T. (2018). Constructivism and Chinese Studie. Journal of Asia-Pacific Studies , 49-63.

Yani, L. (2018). Soft power dan Soft Diplomacy. Jurnal TAPIs, 14(02), 54-55.

Zhang, D. (2018, 01 25). The Concept of 'Community of Common Destiny' in China's Diplomacy: Meaning, Motives and Implications. Asia \& the Pacific Policy Studies, 5(2), 196-207. 